\title{
THE ETHNOGRAPHY OF PRISONS AND PENAL CONFINEMENT
}

\author{
Manuela Cunha, CRIA-UM, IDEMEC-CNRS \\ micunha@ics.uminho.pt
}

(pre-print version)

Posted with permission from the Annual Review of Anthropology, Volume 43 (1):

217-33, (c) by Annual Reviews, http://www.annualreviews.org

\section{Introduction}

Partly following up on L. Rhodes' review of "the history, sociology and anthropology of the prison" (2001), this article centers on the ethnography of carceral institutions and field research on penal confinement. It maps out its contemporary developments and characterizes them in relation to the key themes, predominant theoretical debates and methodological issues that shaped earlier, classic ethnographic approaches to the carceral world.

In line with L. Wacquant's proposition and previous contribution (2002) towards internationalizing the ethnographic discussion around the prison, the review will broaden the hitherto predominantly narrow geographical focus on the United States, extending it also beyond the English-speaking world. ${ }^{1}$ Widening the scope beyond US-centered studies is not simply a question of bringing to bear other realities, adding perspective, and mitigating the risks of parochialism (Ribeiro and Escobar 2006). Broadening the scope is also a matter of necessity insofar as it reflects, as Wacquant also pointed out, the "eclipse" of a rich tradition of prison ethnography in the US, and today's scarcity of "observational studies depicting the everyday world of inmates" (2002: 385). This scarcity, although more recently mitigated, contrasts with the current situation in Europe and Latin America, 
where field researchers are more present in the carceral scene. A widened focus is not tantamount to providing a systematic world tour of prison ethnographic literature, which is not the purpose of this review and would not be viable in its format. Instead, this approach is aimed at contributing to a wider comparative landscape and unified debates based on more diversified sources, which also embody the diversity of prison systems (for an overview see King (2007), Ruggiero et al (1996).

It should also be obvious that the focus on ground-level research does not imply a divorce between micro and macro-level approaches (see in this respect Carrabine 2004). On the contrary, to imply such an opposition would misconstrue and fail do to justice to a great deal of contemporary ethnographic research within the prison or around it. Such research combines different analytic scales and engages with the wider landscape of forms of power, state governance, and cultural and societal transformations. In turn, close-up observation of in-prison aspects contributes to illuminate external processes. In line with the more comprehensive perspective adopted in present-day ethnography, this review will thus also refer to historical, penological and other strands of literature on punishment and society.

The review is built around a main line of discussion, allowing both to aggregate a variety of classic and contemporary studies in a relatively coherent overview, as well as to highlight important shifts in focus and concerns in prison studies over time. The running theme is the "prison-society" nexus and the articulation between the internal and the external world. This articulation is addressed in a variety of ways, whether more centered on the workings of the institution, on institutional agents and practices (examined in the first section), or instead more centered on prisoners and their social world, both within and outside prison walls (examined in the second and third sections). 
In both cases, these are descriptive-ethnographic focuses and are not to be confounded with "prison-centrism" as an ideology endorsing prison itself (Chantraine 2013).

The term "prison" and the main body of field research mentioned in this review concern penitentiaries and medium to high security establishments. Jails, "supermax", and "therapeutic" prisons present particularities that would require specific attention and have been the object of fewer on-the-ground approaches (e.g. Irwin 1985, Rhodes 2004, Genders and Players 2010).

\section{The workings of the institution}

Contemporary ethnographic prison studies do not insulate their localized approach to penal confinement from macro or meso-level social, legal, and political forces. To begin with, these are required to make sense of today's inflated prison populations, resulting from the rise of incarceration rates in most liberal democracies since the last decades of the $20^{\text {th }}$ century - led by the exceptional hyperincarceration in the US. ${ }^{2}$

M. Foucault (1977), who had not predicted this carceral boom and considered prison as an analyzer of society, as a condensed instance of a wider disciplinary rationality pervading society in a specific historical period, had also identified a subsequent historical shift: from a "disciplinary society" to a "security society" based on risk management (Foucault 2009). Since then, several scholars (e.g. Garland 2001, Feeley and Simon 1992, Simon 2007) have explored this new rationale, no longer interested in changing people so much as in dealing with them as they stand, and keeping danger at bay. In other words, a rationale no longer focused on correction but on defense, more concerned with assessing, managing and preventing risks than with redressing offenders' behavior or reintegrating those in the margins of society through welfare.

Although this rationality harbored a liberal critique to the excesses of coercive and intrusive disciplinary power, it also fitted well with punitive penal populism, in a growing 
culture of crime control that appealed to purely retributionist, incapacitating and expressive punishment, devoid of rehabilitation goals. In different ways, other social scientists (e.g. Beckett and Western 2001, Western 2006, Harcourt 2011, Wacquant 2008, 2009) have theorized the current penal expansion mainly as a result of an increase in punishment, rather than in crime. Instead of analyzing the rise in imprisonment rates within a narrow criminological frame, seeking to connect it with fluctuations in crime rates, they matched it with inequality, the neoliberal transformation of the state and the regulation of postindustrial poverty. Market and labor deregulation, coupled with shrinking social welfare, disciplinary social policies and a stronger cultural emphasis on individual responsibility, have converged to exacerbate social inequality in several countries, and to deteriorate the social conditions of an urban precariat, whose problems and disorders are dealt with by the penal system. And if and "governing through crime" (Simon 2007) gains appeal in post-industrial societies, albeit in variable degrees, it is also because the state reasserts public authority mainly through the penal system (Wacquant 2008, 2009). Wacquant has thus considered the prison as a key institution for a sociology of the regulation of poverty and for a historical anthropology of the state.

These broad interrelated tendencies have filtered down to the level of prison regimes themselves, as on-the-ground research mentioned in this section illustrates. However, this research also exemplifies that the state is not to be understood as a singular undifferentiated entity, with clear-cut boundaries and acting in a consistent and uniform fashion. It is a diversified web of institutions, procedures, rationalities and actors coexisting in a complex and sometimes contradictory manner (Ferguson and Gupta 2002; Lipsky 1980). The state can in turn be approached ethnographically trough the workings of its institutions, where policies and practices meet and are also produced at the level of its agents' everyday activity. 
Changing general trends can be identified in penal institutions, but they do not necessarily indicate a unified and coherent rationality. The focus on existing practices and daily routines can reveal composite layers from different penal eras. Post-modern prison programs can coexist with old modernist classifications and disciplinarities, alongside with pre-modern modes of control such as body searches, physical coercion, and neofeudal acts of punishment like deportations, public humiliation and shaming procedures (Carlen and Tombs 2006: 356, Shearing 2001).

The rehabilitative ideal did not disappeared with the punitive turn altogether, and neither did it decline to the same degree everywhere (Carrier 2010, Whitman 2003), even if it took on new forms. Some of its reconfigurations are especially noticeable in women's prisons. P. Carlen and J. Tombs (2006, also Kendall and Pollack 2003, Hanna-Moffat 2001) have analyzed local implementations of a contemporary avatar of disciplining, in the form of in-prison cognitive-behavioral programs that, contrary to classic disciplinary governance, no longer emerge within the confines of nation states, but emanate from a global market of penal products described as "re-integration industries". Fuelled by the revival of psychological perspectives on crime and oblivious to adverse backgrounds or severe social situations prisoners face, these programs aim to reduce recidivism by redefining prisoners' predicaments as psychological problems in need of cognitive adjustments. Recent ethnographic research has also identified a similar tendency in community-based institutions for the correctional treatment of women offenders (Haney 2010).

Disciplines can therefore resurface in this commodified remix of treatment and punishment. But previous disciplinary techniques, such as work and surveillance, have also been noted to lose disciplinary content and to acquire new meanings. More than acting on prisoners' dispositions, inducing regularity and self-control, prison work can be 
viewed by prisoners and administrators as a right that insures the means for purchasing consumer goods, which becomes all the more important as prison populations are increasingly poor (Cunha 2002, Faugeron 1996, Marchetti 2002). More than re-enacting a panoptical essence in its most refined expression, where permanent monitorization was meant to produce "docile bodies", the sophistication of technological surveillance can be directed above all at maximizing security (Santoro 2005). Supermax custody takes the control over prisoners through this and other devices to the extreme (Rhodes 2004).

The focuses on rehabilitation and punishment can also resurface recombined with, or transformed by, the post-modern emphasis on risk management, through a managerialized and, like other globalized policies, standardized approach. Accordingly, notions of "risk as social deprivation" give way to an idea of "risk as dangerousness". Rehabilitation interventions centered on prisoners' needs are redefined by the assessment and management of the risk they may pose for public security, together with a postdisciplinary stress on prisoners' individual responsibility and a volitionist emphasis on their autonomous capacity of choice as moral agents (Bosworth 2007, Hanna-Moffat 2001).

This redefinition of the institution's mission can be illustrated by the shift in the recruitment pool, ethos and practices of non-correctional prison staff - now probation officers - from social work to the legal-criminological field, richly ethnographed in two French carceral institutions by Y. Bouagga (2012). Bouagga also showed that, rather than a single systemic intentionality, the carceral field was spanned by multiple positions and different tendencies, embedded in concrete social relations and in the work of frontline personnel, within a variety of specific constraints, occupational cultures, subjectivities and moral configurations. In a similar vein, detailed field studies have described the contradictions and moral tensions involved in the daily practices of institutional agents, 
and how new modes of governance such as managerialism, focused on organizational performance, measurable processes, administrative efficacy and cost-effectiveness, combine with local circumstances to produce specific effects at the institutional level (e.g. Carrabine 2004, Liebling 2004, Cheliotis 2006, Bennet et al 2008, Crawley 2004, Chauvenet 1994).

Accountability in today's carceral institutions is not, however, limited to an economic dimension, being also endowed with a moral meaning. As a coercive institution, the prison incurs in a fundamental suspicion of illegitimacy within a framework of human rights that has set the limits to punishment and has periodically inspired prison reforms in most liberal democracies. Expectations of decency, respect for prisoners' dignity and rights, and humanization in carceral treatment - also part of a liberal ethics of power -, have motivated guidelines and standards regarding living conditions, prisoners' basic opportunities and entitlement. Field studies and ethnographic approaches suggest that, rather than dismiss this orientation as a mere front disguising the deleterious effects of imprisonment and the severity of coercive treatment inspired by a punitive political atmosphere, it is more productive to examine the concrete modalities by which it coexists with other, contradictory forces within the institution; how it is implemented or recedes in specific circumstances, and how formal guarantees are not enough to insure fairness and equity - and may even compound structural inequality for those prisoners lacking the resources or the cultural skills to "play the game" in terms of the institutional expectations placed on them, especially in a more codified, bureaucratized environment (e.g. Bouagga 2012, Crewe 2009, Cunha 2002, Liebling 2004). ${ }^{3}$ However, the formalization of a variety of daily procedures and interactions - from control to communication and decision-making -, moderates and contains the excesses of institutional power insofar as it contributes for minimizing overt discrimination, and 
provides prisoners with means for challenging blatant arbitrariness (Cheliotis 2006, Easton 2011).

There is thus a long-term tendency towards the moralization of the institution through the humanization of prison regimes and a stricter regulation of coercive power. Aspects of this tendency are also known as "normalization", a notion that when applied to prison, rather than prisoners, is devoid of its foucauldian disciplinarian connotations and has entered the lexicon of prison officials in several European countries with an entirely different meaning: it refers to the prison as one amongst many institutions providing a public service, and a "normal" sub-system of society. Prisons should thus aim to reduce the gap between the inside and the outside world, and to mirror free society in central aspects of human existence (from civic to sexual aspects) (Leander 1995, Snacken 2002). This orientation therefore challenges a "less eligibility" principle, which inversely advocates their permanence below mainstream society standards in order to remain aversive and deterrent (Easton 2011, Sieh 1989). Normalization has been implemented in varied forms and degrees, in chronic tension with "less eligibility" and within limits variably set by security concerns, which tend to prevail in carceral institutions.

Normalization can be reflected in several practices, whether at the level of individual prisoners, considered in their personal and social identities, or at the level of the institution and the services available. It the first case, normalization can consist in not replacing previous identities by a prisoner identity in the form of a number or a prison uniform. In the second case, it consists in sustaining, rather than reducing, access to education, health, training, as well as other aspects such as intimate conjugal visits or voting rights (Easton 2011, Snacken 2002). ${ }^{4}$ This access is not strictly intramural. Normalization can be based on a wider perspective of prisoners' social inclusion and citizenship integration, upholding their rights not only as prisoners but as full citizens. As 
such, it can include institutional actions to promote prisoners' access to general social benefits, healthcare coverage and social security. ${ }^{5}$ It also entails a closer integration with other sectors of public administration, and a stronger articulation with other public or private entities for the provision of goods and services no longer organized within a separate prison sector.

This closer integration, which has rendered prison walls more permeable, also concerns modes of regulation and outside scrutiny that limit the local margins of discretion of carceral institutions. Their normative order has been relocated at higher levels, not only national but also transnational or supra-national levels. ${ }^{6}$ Prison regimes, timetables and daily rules are no longer entirely decided at the local level of confinement settings, but follow centralized orientations. Procedural scrutiny and organizational oversight by upper echelons of both prison and non-prison authorities, centralization and bureaucratization of institutional decision-making, formalization of guidelines and standardization of procedures have also shifted the locus of power and authority. They have resulted in a tighter frame, reshaping the action of prison staff and managers - and, indirectly, prisoners' social configurations. Given the reduced latitude to interpret and implement prison rules, correctional management is less prone to reflect prison governors' personal style and idiosyncrasies, but is also less inclined to negotiate order with informal parallel structures of authority among prisoners, for example by co-opting prisoner leaders to institutional governance. Instead, together with the institutional stress on individual responsibility and self-regulation, it contributes to individualize the prisoner community (Adler and Longhurst 1994, Barak-Glanz 1981, Bryan 2007, Crewe 2009, Cunha 2002, Liebling 2004, Sparks et al 1996). ${ }^{7}$ Ethnographic accounts of prisons in the global South have pointed nevertheless to a coexistence of formalization and 
informalization processes in institutional governance (e.g. Barbosa 2007, Castro e Silva 2011, Garces, Martin and Darke 2013).

It is on the grounds of the decline of closed, authoritarian institutional regimes, the narrowing gap with mainstream society in terms of standards and living conditions, and the growing flow of goods, services and communications (Jewkes 2002) which traverse prison walls, that the present relevance of the goffmanian model of the prison as a "total institution" (Goffman 1961) has been most commonly challenged (e.g. Chantraine 2004, Davies 1989, Lemire and Vacheret, 2007; Farrington, 1992).

\section{The prison beyond walls}

Field studies have looked beyond the institution's physical walls in yet other ways. Focusing on the peri-carceral space of the institution, one type of ethnographic enquiry examines the exchanges with the proximate socio-spatial environment surrounding carceral settings, especially how the effects of the prison's penal stigma project onto its immediate spatial vicinity. Social ecology studies conducted around French penitentiaries are one example. They shed light on the practices of social relegation and symbolic distancing that take place in the "sensitive perimeter" of the prison (Combessie 2001, see also Marchetti 1996, Renouard 1999), reinforcing a cleavage that marks it off from free society. R. Sabaini's (2011) rich ethnography documenting the social absorption of two penitentiaries by a Brazilian town provides another example.

In a different vein, other approaches have focused on the social and relational perimeter of the prison, and have closely characterized how incarceration shapes and affects prisoner's families, partners, and communities. Reaching beyond incarcerated individuals and capturing the collective dimension of imprisonment beyond walls, these approaches have become all the more important as the rise of incarceration rates revealed 
a disproportionate concentration on ethnic-racial minorities and impoverished communities (Wacquant 2013, Patillo et al 2004, Western 2006). High levels of concentrated incarceration have resulted in the ubiquity of prison as an existence woven into the fabric of poor urban neighborhoods, where the lives of residents and families are pervaded by the prison system's inescapable presence, with specific community-level depleting effects ranging from social to economic, civic and political (e.g. Braman 2004, Clear 2007, Clear et al 2001, Cunha 2008, Patillo et al 2004). Ethnographic studies have also shown how massive imprisonment has reshaped kinship and neighborhood networks, and how it impacted on informal structures of social support (Cunha 2013).

Bringing the lens closer to the prisoners' loved ones on the outside, an important body of field research has shed light on an "extended carceral experience" (Touraut 2012) that includes the challenges and difficulties - financial, social, emotional - faced by prisoners' families and partners during imprisonment, and, on the other hand, the material, moral and emotional support they bring to those behind bars. ${ }^{8}$ In-depth ethnographic enquiries have brought nuances to assumptions that incarceration fuels disruption or causes the breakdown of interpersonal ties, and have complexified recurring analysis in terms of simple gains or losses for families or prisoners. C. Touraut (2012) in France, and M. Comfort (2008) in the US, for example, have illustrated how experiences can be diverse depending on interpersonal and socio-economic circumstances, how relationships maintained across bars can be ridden with ambivalence, and how both individuals and relationships are reconfigured by incarceration.

Comfort described the "secondary prisonization" of women with incarcerated partners, a process of socialization to carceral norms and subjection to penal control that induces them to rely upon the correctional authorities as the most consistent public institution available to them. She showed a coexistence of disintegrative and integrative 
effects of incarceration, and described how prison becomes a distorted but manageable substitute site for domestic and conjugal life. Shielded from violent behavior and home turmoil, women can sustain with some measure of control otherwise problematic relationships. They also find identity gains in re-inscribing themselves in the gendered roles of nurturer and caregiver.

Other ethnographies (e.g. Cunha and Granja 2014, in Portugal, Palomar Verea 2007, in Mexico) have identified a similar process of reconfiguration in the case of incarcerated women and parent-child relationships. Separation from children may be a constant source of stress and generate feelings of being a "bad mother" But imprisonment also allows inmate mothers to re-elaborate problematic mother-child relationships in a different light. Moreover, in correctional facilities where inmate mothers can keep their infant children with them, the prison environment may allow for experiencing motherhood in new ways, creating new subjectivities through which mothers in turn resignify previous experiences of maternity: sheltered from the pressures of everyday survival, poverty and violence, with time available to dedicate to their children - who also start to receive medical and psychological expert attention --, they may experience with unprecedented intensity a bond with their children, endowing it with a meaning that takes center stage in their lives thereon. In such a context, motherhood becomes hyperbolized in narratives of personal identity. In both of these cases -- conjugal and parental relationships under the shadow of the prison--, these lesser known distorting effects of incarceration are not unrelated to the fact that the penal institution has also become a "peculiar social service" for managing problems unaddressed by other means and institutions, especially at a time of retrenchment of the welfare state (Comfort 2008).

\section{Prisoners' social and subjective world}


More prisoner-centered, a rich and ongoing tradition of prison ethnography has explored the prisoners' social and subjective world behind bars, from its cultural forms, social relations and structures, to the forms of power, adaptation and resistance deployed in the specific moral and material world of confinement institutions. These aspects have been approached in a more or less interconnected manner. The notions of "prison culture" and "prisoner society", and the ethnographic attention devoted to the inner world of carceral institutions, gained currency in the aftermath of D. Clemmer's theory of prisonization (1940), a process of socialization into inmate values that, according to Clemmer, would hinder rehabilitation. G. Sykes (1958) and Sykes and S. Messinger (1960) shifted the focus from prisonization to the culture itself, a system of values and norms in the form of injunctions ("do's" and "don'ts") guiding prisoners behavior and defining typical social roles that could be found across diverse prison populations. ${ }^{9}$ They theorized prison culture as a collective response to obviate an array of material and moral deprivations entailed by imprisonment, thus as a mechanism with roots in prison itself. J. Irwin and D. Cressey (1962) would later argue that although inmate culture and society provided means to cope with imprisonment, it was not generated by prison-specific properties, but was instead a coalescence of external subcultures imported into the prison.

Since this first formulation of the "deprivation-importation" debate interrogating the endogenous or exogenous basis of prison culture and social life, and which continues to reverberate in more or less integrated versions of the two models in present-day literature (e.g. Crewe 2009, Harvey 2007, Trammell 2012), it was thus the prisoner community itself - besides institutional power - that gradually ceased to be considered a self-contained system. And although at its early stages both sides of the debate converged in their common recognition of a relatively unified community, stabilized by a single specific cultural form regardless of its origins (see Irwin 1970), the prisoner community 
would in later years be described as fragmented into mutually hostile factions, with their own normative codes to which only their members were bound. These were factions divided along ethnic-minority lines, gang membership, and violent groups from the street drug economy (e.g. Carroll 1974, Colvin 1992, Fleisher 1989, Irwin 1980, 2005, Jacobs 1977).

External structural conditions, along with cultural ones, therefore became more present in ethnographic accounts of the prisoner community and of its permeability to the outside world. Still, external worlds integrated these accounts mostly as background, as the previous context that molded prisoners' moral world and cultural forms, and impacted on prison's social structure. But the carceral co-presence of gang members, affiliates from the streets, "mates", "road dogs", "homeboys" or "homegirls" (Carroll 1974, Días-Cotto 1996, Fleisher 1989, Irwin 1980, Jacobs 1974, Morris and Morris 1963) also meant that prison walls did not entirely cut prisoners from their social world, that segments of this world were also transposed into prison and continued to back previous social identities.

Later on, phenomena of concentrated incarceration that tightly interlocked carceral institutions and lower-class, heavily penalized communities, observed in the US and in other countries (e.g. Barbosa 2006, Biondi 2010, Clear 2007, Cunha 2002, 2010, Wacquant 2013), would further call into question the boundaries of the prison as a micro social scene. M. Cunha's ethnographic revisit $(2002,2008)$ of a women's prison in Portugal showed how carceral sociality ceased to be self-referential and became an extension of some urban neighborhoods. Its course became tightly bound to the flow of everyday life outside through the ramifying networks that connected prisoners both among them and to external overlapping circles of kin, friends and neighbors. These constellations transformed the experience of confinement and synchronized prison temporality with the rhythms of the outside world. Unlike her previous "prison-in- 
context" type of ethnography in the same institution, she was led to shift the ethnographic focus from the prison to the interface mediating the inside and the outside, the prison and the neighborhood, in order to capture the new translocality of carceral social life. Highlighting not only the porosity of institutional prison boundaries (see above), but also a more subterranean porosity in the prisoner social world, this type of approach takes the break with goffmanian-type depictions of the prison as "a world apart" a step further (see also Crewe 2009, Bandyopadhyay 2010).

\section{Reflexivity in prison field research}

The interlocking of inside and outside worlds at multiple levels raises new methodological questions about the boundaries of the prison as a site of field enquiry. The political and practical conditions of the production of prison field research also continue to deserve consideration. Depending on the funding entities, the research design itself may be pre-determined by policy-driven and utilitarian agendas, or pursue more autonomous and theoretically-driven concerns. In a closed, coercive environment, the issue of accessibility is paramount for the viability of in-depth, long-term ethnographic research, which by definition includes not only "scheduled" interviews and narratives, but also serendipitous, non-elicited data provided by close-up, unstructured observation and informal conversations. "Quasi-ethnography" is a justified expression given that fieldworkers' access to carceral settings with little or no institutional filters is rare in international prison research (Rhodes 2001, Wacquant 2002, Waldram 2009). There is, however, non-negligible an amount of present-day ethnographies, especially on European prisons, which have benefitted from full, unrestricted and unconditioned access to prisoners and prison premises (e.g. Rowe 2011, Crewe 2009, Cunha 2002, 2008, Ugevik 2012). 
Besides a specific exploration of ethnographic avenues and qualitative techniques in carceral contexts, such as interviewing (e.g. Davies 2000, Jenness 2010, Sutton 2011), life stories, self-narratives, and auto-ethnography (Crewe and Maruna 2006, Jewkes 2012), prison field research has also reflectively addressed its own "situatedness". Prison ethnographers' have problematized their own social location in terms of ethnicity, gender, class and age (Phillips and Earle 2010); their overt or covert role as researcher (Cohen and Taylor 1972); the actual or imputed position as prisoner (Kaminski 2004, Spedding 1999), ${ }^{10}$ guard (Fleisher 1989, Marquart 1986), visitor (Biondi 2010), student, social worker (Le Caisne 2000), and other forms of identity management (King and Wincup 2000).

This explicit awareness also concerns fieldworkers' relationship with their interlocutors, emotional and intellectual engagement, intimacy and detachment, and navigating the relationships between different groups and power structures (Liebling 2001, Nielson 2010, Sparks2002, Sloan and Drake, 2013; see also King and Wincup 2000). Other than simply confessional, these aspects can be sociologically folded into the process through which ethnographers come to understand the dynamics of the carceral world they study (Rhodes 2001). Even the much commented position of the prison ethnographer as an "outsider" does not preclude his/her absorption into this dynamics and can contribute to illuminate it, whether this exteriority hinders or facilitates social rapport - or does both, in different moments and circumstances (Cunha 1994, 2002).

An awareness of the historicity and cultural context of the ethnographic enquiry takes reflexivity to a wider level. It allows for a more grounded and systematic articulation between individual, intersubjective, social, and institutional aspects, providing a comparative background against which separate assumptions related with these aspects can be (re)assessed. Ethnographic revisits of the same carceral site - combined or not 
with cross-institutional comparisons (e.g. Cunha 2002, Genders and Players 2010, Kruttschnitt and Gartner 2005, Liebling 2013) - capture change, but temporal context also allows for a more accurate identification of carceral situations' specific properties, as well as of the nature of the factors that shape them.

Prison ethnographies conducted in cultural contexts other than Anglo-American ones, where the dominant framing of prison studies occurred, show how different cultural varieties of incarceration can combine with globalized forms of penal power. They also contribute to a comparative understanding of the fusing of prison-specific and culturespecific aspects of carceral worlds (Bandyopadhyay 2010, Bandyopadhyay, Jefferson and Ugelvik 2013, Garces, Martin and Darke 2013, Piacentini 2004, 2007, Reed 2004). In a related vein, a diversified prison ethnographic landscape can enhance reflexivity in terms of the categories used in ethnographic analysis. Categories of race/ethnicity, to name one example, are highly variable cultural constructs - and variable social and administrative classifications -- that cannot be imported without precaution from, say, US contexts to Iberian or postcolonial Latin American ones. ${ }^{11}$ Examining the contextual meanings of race/ethnicity as categories of identity and social organization in a Portuguese prison, Cunha $(2002,2010)$, for example, noted that these categories had specific contours and could not simply be described in terms of their relative unimportance when compared to US prisons. In the external environment they were also differently shaped by a specific interplay with class, mediated by conditions such as the neighbourhood and the specific form of the Portuguese retail drug economy. Other ethnographies in European prisons have also shown how locality, cultural background, religion and commonalities of experience supersede race/ethnicity in prison social life, even when they appear to coincide with ethno-racial alignments (Crewe 2009, Genders and Players 1989, Khosrokhavar 2004, Phillips and Earle 2010). 
Prison field approaches have reflected general theoretical debates on ethnicity/race, class, gender, and the intersections between them. Gender, however, has informed prison research in a distinct manner depending on whether it focused on men's or women's prisons. Research on men's prisons is no longer oblivious to gender, and has come to acknowledge this dimension, especially regarding the ideologies of masculinity that shape prison culture (Newton 1994, Sabo et al. 2001). Research on women's prisons, however, has tended to be more gender-bound as a whole. The analytic angle of gender has presided to most research issues: from the gendered nature of prison regimes (based on normative femininity and domesticity, or more gender-neutral, Bosworth 1999, Carlen 1983, Kruttschnitt and Gartner 2005, Miller and Carbone-Lopez 2013, McCorkel 2003), prison cultures, socialities and "pains of imprisonment" (predicated on gender roles and identities, and contrasted with their males equivalents, Giallombardo 1966, Heffernan 1972, Walker and Worrall 2000, Ward e Kassebaum 1965, Zaitzow and Thomas 2003), to issues of representation (the conundrums of representing women as victims and/or agents, Fili 2013).

This more "gendercentric" agenda is nevertheless increasingly diversified for theoretical and empirical reasons alike. These involve recognition of the diversity of women prisoners' experiences and identities, attention to a wider variety of aspects of carceral life, but also changes inside and outside prison walls, and contextual shifts in the actual saliency of gender as a category of identity and social life in women's prisons (Boutron and Constant 2013, Cunha and Granja 2014, Greer 2000, Mandaraka-Sheppard 1986, Owen 1998, Rowe 2011).

\section{Concluding remarks}


Prison-society relations and the articulation between the internal and the external world have been more or less apparent in ground-level enquiries of the carceral world. These relations have been examined from different perspectives, within and across different scales and analytic frames. From an institution-centered perspective, the relation of prisons with the world beyond its walls has been approached focusing on the external influences that bear upon confinement institutions, and specifically upon institutional enactments of coercive power. Broader shifts in rationalities, governmentality and punishment policies, as well as the relocation of the normative basis and locus of authority to levels superseding individual institutions, have impacted on how institutional power is exerted - which in turn shapes prisoner's experiences of incarceration. The narrowing of the gap with mainstream society in standards and living conditions, and the growing flow of goods, services and communications that traverse prison walls have also come into onthe-ground focus. This institutional porosity in terms of modes of provision, regulation and scrutiny dismisses a view of the carceral world as autarchic, closed and self-sufficient, while it reveals, at the same time, the growing complexity of contemporary modes of the exercise of power - a complexity that can include the coexistence of contradictory practices and rationalities.

Besides this examination of the institution-in-context, that is, in the light of macro or meso-level conditions which shape institutional power and the workings of the institution, the permeability of prison boundaries has been problematized and documented ethnographically in yet other ways. Other prison-in-context approaches, centered on the prisoner community, highlight this permeability in terms of the previous external universes that shape prisoners' identities, moral world, cultural forms and social structures behind bars. 
Whether centered on the intra-mural life of prisoners or on the extra-mural life of their families, partners and communities, "interface" approaches have shifted in different ways the ethnographic focus to the juncture of both social worlds and have shed light on their mutual effects, as well as on their mutual constitution in times of massive, concentrated incarceration that disproportionately affects particular categories of people. In the case of prison field studies, these approaches capture more subterranean porosities and problematize the boundaries of the carceral setting as a micro social scene that became translocal.

A closer attention to prison-society relations, and a growing acknowledgement of the porosity of what was once depicted as a closed, bounded universe, reflect macro and micro-level shifts in empirical realities, but is also attuned to shifts in broader theoretical debates, where aspects of flow or closure (Geschiere and Meyer 1998) are more or less emphasized. Prison field research has also embodied broader debates by becoming more reflexively aware of the manifold conditions of its own production. 


\section{Literature Cited}

Adler M, Longhurst B. 1994. Discourse, Power and Justice. Towards a New Sociology of Imprisonment. New York: Routledge

Bandyopadhyay M. 2010. Everyday life in an Indian prison. Confinement, surveillance, resistance. New Delhi: Orient BlackSwan

Bandyopadhyay M, Jefferson A, Ugelvik T. 2013. Prison spaces and beyond: the potential of ethnographic zoom. Crim. Justice Matters, 91 (1): 28-29

Barak-Glanz, IL. 1981. Towards a conceptual schema of prison management styles. Prison J. 61 (2) 42-60

Barbosa, AR. 2006. O baile e a prisão: onde se juntam as pontas dos segmentos locais que respondem pela dinâmica do tráfico de drogas no Rio de Janeiro. Especiaria. 9: 11934

Barbosa, AR. 2007. Um levantamento introdutório das práticas de violência física dentro das cadeiras cariocas. In Conflitos, Política e Relações pessoais, ed. AC Marques, pp. 129-72. Campinas: Pontes Editora

Beckett K, Western B. 2001. Governing social marginality. Welfare, incarceration, and the transformation of state policy. Punishm. \& Soc. 3 (1): 43-59.

Bennett J, Crewe B, Wahidin A, eds. 2008. Understanding Prison Staff. Cullompton: Willan

Biondi J. 2010. Junto e Misturado. Uma Etnografia do PCC. São Paulo. Editora Terceiro Nome

Bouagga Y. 2012. Le métier de conseiller d'insertion et de probation: dans les coulisses de l'État pénal? Sociol. Trav. 54 (3): 317-37

Boutron C, Constant C. 2013. Gendering transnational criminality. The case of women's imprisonment in Peru. Signs. 39 (1): 177-95

Bosworth M. 1999. Engendering Resistance: Agency and Power in Women's Prisons. Dartmouth: Ashgate

Bosworth M, Campbell D, Demby B, Ferranti SM, Santos M. 2005. Doing prison research: views from the inside. Qual. Inq. 11: 249-64

Bosworth M. 2007. Creating the responsible prisoner. Federal admission and orientation packs. Punishm. \& Soc. 9 (1): 67-85

Braman D. 2004. Doing time on the outside: incarceration and family life in America. Ann Arbor: University of Michigan Press

Bryan S. 2007. Managing Prisons in a Time of Change. Cullompton: Willan 
Carlen P. 1983. Women's Imprisonment: A Study in Social Control. London: Routledge and Kegan Paul.

Carlen P, Tombs J. 2006. Reconfigurations of penality. The ongoing case of the women's imprisonment and reintegration industries. Theor. Criminolog. 10 (13): 337-60

Carrabine E. 2004. Power, Discourse and Resistance. A Genealogy of the Strangeways Riot, Dartmouth: Ashgate

Carrier N. 2010. Sociologies anglo-saxonnes du virage punitif. Champ pénal / Penal field, nouvelle revue internationale de criminologie. VII (23). http://champpenal.revues.org/7818

Carroll L. 1974. Hacks, Blacks and Cons. Race Relations in a Maximum Security Prison. Illinois: Waveland Press

Castro e Silva AM. 2011. Participo que...Desvelando a Punição Intramuros. Rio de Janeiro: Publit

Chantraine G. 2004. Par-delà les Murs. Expériences et Trajectoires en Maison d'Arrêt. Paris: PUF

Chantraine G. 2013. Prisons under the lens of ethographic criticism, Crim. Justice Matters, 91 (1): 30-31

Chauvenet A, Orlic F. 1994. Le Monde des Surveillants de Prison. Paris: P.U.F

Cheliotis L. 2006. How iron is the iron cage of new penology? The role of human agency in the implementation of criminal justice policy. Punishm. \& Soc. 8 (3): 313-40

Clear TR. 2007. Imprisoning Communities. How Mass Incarceration Makes Disadvantaged Neighborhoods Worse. New York: Oxford University Press

Clear T, Rose DR, Ryder JA. 2001. Incarceration and community: the problem of removing and returning offenders. Crime Delinq. 47 (3): 335-51

Clemmer D. 1940. The Prison Community. New York: Rinehart \& Co

Cohen S, Taylor L. 1972. Psychological Survival: The Experience of Long-Term Imprisonment. Harmondsworth: Penguin Books

Colvin M. 1992. The Penitentiary in Crisis. Accommodation to Riot in New Mexico, New York: State University of New York Press

Combessie P. 2002. Marking the carceral boundary. Penal stigma in the long shadow of the prison. Ethnography, 3(4): 535-55

Comfort ML. 2008. Doing Time Together: Forging Love and Family in the Shadow of the Prison. Chicago: Chicago University Press 
Crawley E. 2004. Doing Prison Work. The Public and Private Lives of Prison Officers. Cullompton: Willan

Crewe B. 2009. The Prisoner Society: Power, Adaptation, and Social Life in an English Prison. Oxford: Oxford University Press

Crewe B, Maruna S. 2006. Self-narratives and ethnographic fieldwork, In The Handbook of Fieldwork, ed. D Hobbs, R Wright: 109-24. London/Thousand Oaks CA: Sage

Cunha M. 1994. Malhas que a reclusão tece. Questões de identidade numa prisão feminina. Lisbon: CEJ

Cunha M. 2002. Entre o Bairro e a Prisão: Tráfico e Trajectos, Lisbon, Fim de Século

Cunha M. 2008, Closed circuits: kinship, neighborhood and imprisonment in urban portugal, Ethnography, 9 (3): 325-50

Cunha M. 2010. Race, crime and criminal justice in Portugal. In Race, Crime and Criminal Justice: International Perspectives, ed. A Kalunta-Crumpton, 144-61. New York: Palgrave MacMillan

Cunha M. 2013. The changing scale of imprisonment and the transformation of care: the erosion of the 'welfare society' by the 'penal state' in contemporary Portugal. In Ethnographies of Social Support, ed. M Schlecker, F Fleischer: 81-101. New York: Palgrave MacMillan.

Cunha M, Granja R. 2014. Gender asymmetries, parenthood and confinement in two Portuguese prisons. Champ Pénal/Penal Field. In press

Davies C. 1989. Goffman's concept of the total institution: criticism and revisions. Hum. Stud. 12: 77-95

Davies P. 2000. Doing interviews with female offenders. In Doing Criminological Research, ed. V Jupp, P Davies, P Francis: 82-96. Thousand Oaks, CA: Sage

Díaz-Cotto J. 1996. Gender, Ethnicity and the State. Latina and Latino Prison Politics. New York: State University of New York Press

Easton S. 2011. Prisoners' Rights: Principles and Practice S. Easton. London: Routledge

Farrington K. 1992. The modern prison as total institution? Public perception versus objective reality. Crime \& Delinq. 38 (1): 6-26

Faugeron C. 1996. The Changing Functions of Imprisonment. In Prisons 2000. An International Perspective on the Current State and Future of Imprisonment, ed. $\mathrm{R}$ Mathews, P Francis: 121-38. London: McMillan Press

Feeley M, Simon J. 1992. The new penology: notes on the emerging strategy of corrections and its implications. Criminology 30 (4): 449-74 
Ferguson J, Gupta A. 2002. Spatializing states: toward an ethnography of neoliberal governmentality. Am. Ethnol. 29 (2): 981-1002

Fili A. 2013. Women in prison: victims or resisters. Representations of agency in women's prisons in Greece. Signs. 39 (1): 1-26

Fleisher MS. 1989. Warehousing Violence. California: Sage Publications

Foucault M. 1977. Discipline and Punish: The Birth of the Prison. Trans. Sheridan A. London: Penguin

Foucault M. 2009. Security, Territory, Population: Lectures at the College de France 1977-1978. New York: Picador

Garces C, Martin T, Darke S. 2013. Informal prison dynamics in Africa and Latin America" Crim. Justice Matters, 91 (1): 26-26

Garland D. 2001. The Culture of Control. Crime and Social Order in Contemporary Society. Oxford University Press

Genders E, Players E. 1989. Race Relations in Prison. Oxford University Press.

Genders E, Players E. 2010. Revisiting Grendon 20 years on. The Howard J. 49 (5): 43150

Geschiere P, Meyer B. 1998. Globalization and Identity: Dialectics of Flow and Closure. Oxford: Blackwell

Giallombardo R. 1966. Society of Women. A Study of a Women's Prison. New York: John Wiley \& Sons.

Goffman E. 1961. Asylums: Essays on the Social Situation of Mental Patients and Other Inmates. Harmondsworth: Penguin

Greer K. 2000. The changing nature of interpersonal relationships in a women's prison. Prison J. 80 (4): 442-68

Haney LA. 2010. Offending Women: Power, Punishment, and the Regulation of Desire. University of California Press

Hanna-Moffat K. 2001. Punishment in Disguise. Governance and Federal Imprisonment of Women in Canada. Toronto: University of Toronto Press

Harcourt BE. 2011. The Illusion of Free Markets: Punishment and the Myth of Natural order. 1 vol. Cambridge, Mass: Harvard University Press

Harvey J. 2007. Young Men in Prison. Surviving and Adapting to Life Inside. Cullompton: Willan 
Heffernan E. 1972. Making It in Prison. The Square, The Cool and The Life. New York: John Wiley \& Sons

Irwin J. 1970. The Felon. New Jersey: Prentice-Hall

Irwin J. 1980. Prisons in Turmoil. Boston: Little, Brown and Company

Irwin J. 1985. The Jail. Berkeley CA: University of California Press

Irwin J. 2005. The Warehouse Prison. Disposing of the New Dangerous Classes. Los Angeles: Roxbury

Irwin J, Cressey D. 1962. Thieves, convicts and the inmate culture, Soc. Probl., 10: 14255

Jacobs J. 1974. Street gangs behind bars, Soc. Probl., 21 (3): 395-409

Jacobs J. 1977. Stateville. The Penitentiary in Mass Society. Chicago: University of Chicago Press

Jenness V. 2010. From policy to prisoners to people: a soft mixed methods approach to studying transgender prisoners. J. Contemp.

Ethnogr. 39 (5):517-53

Jewkes, Yvonne. 2002. Captive Audience. Media, Masculinity and Power in Prisons. Cullompton: Willan

Jewkes Y. 2012. Autoethnography and emotion as intellectual resources: Doing prison research differently. Qual. Inq. January. (1) 18: 63-75

Kaminski M. 2004. Games Prisoners Play. The tragicomic Worlds of Polish Prison. Princeton NJ: Princeton University Press

Kendall K, Pollack S. 2003. Cognitive behaviouralism in women's prisons: a critical analysis of therapeutic assumptions and practices in B. Bloom (ed.) Gendered Justice. Addressing Female Offenders. Durham NC: Carolina Academic Press: 69-96

Khosrokhavar F. 2004. L'islam dans les prisons. Paris: Éditions Balland

King R. 2007. Imprisonment: Some International comparisons and the need to revisit panopticism, in Yvonne Jewkes (ed.) Handbook on Prisons. New York: Willan Publishing

King R, Wincup E. (eds.) 2000. Doing Research on Crime and Justice. Oxford: Oxford University Press

Kruttschnitt C, Gartner R. 2005. Marking Time in the Golden State: Women's Imprisonment in California. Cambridge: Cambridge University Press 
Leander K. 1995. The Normalization of Swedish Prisons, in V. Ruggiero; M. Ryan; J.

Sim (eds), Western European Penal Systems. A Critical Anatomy. London: Sage: 167-93

Le Caisne L. 2000. Prison. Une Ethnologue en Centrale. Paris : Editions Odile Jacob

Lemire G, Vacheret M. 2007. Anatomie de la Prison Contemporaine. Montréal : Presses de l'Université de Montréal

Liebling A. 2001. Whose side are we on? Theory, practice and allegiances in prison research. Br. J. Criminolog. 41: 472-84

Liebling A. 2013. Identity and emotion in a high security prison. Crim. Justice Matters, 91 (1): $22-23$

Liebling A, Arnold H. 2004. Prisons and Their Moral Performance. A Study of Values, Quality and Prison Life. Oxford: Clarendon Press

Lipsky M. 1980. Street-Level Bureaucracy: Dilemmas of the Individual in Public Services. New York: Russel Sage Foundation

Mandaraka-Sheppard A. 1986. The Dynamics of Agression in Women's Prisons in England. London: Gower

Marquart JW. 1986. Doing research in prison: the strengths and weaknesses of full participation as a guard. Justice $Q$. 3(1):15-32

Marchetti A, Combessie P. 1996. La prison dans la cité. Paris : Desclée de Brouwer

Marchetti A. 2002. Carceral Impoverishment. Class Inequality in the French Penitentiary. Ethnography: 3(4): 416-34

Mathiesen T. 1965. The Defences of the Weak. A Sociological Study of a Norwegian Correctional Institution. London: Tavistock

McCorkell JA. 2003. Embodied Surveillance and the Gendering of Punishment. $J$. Contemp. Ethnogr. 32 (1): 41-76

Mele C, Miller TA (Eds.). 2005. Civil Penalties, Social Consequences. New York: Routledge

Miller J, Carbone-Lopez K. 2013. Gendered carceral regimes in Sri-Lanka: colonial laws, post-colonial practices and the social control of sex workers. Signs, 39 (1): 79-103

Mills A, Codd H. 2007. Prisoner's' Families in Yvonne Jewkes (ed.) Handbook on Prisons. New York: Willan Publishing: 672-95

Morris P, Morris T. 1963. Pentonville. A Sociological Study of an English Prison. London: Routledge 
Newton C. 1994. Gender theory and prison sociology: using theories of masculinities to interpret the sociology of prisons for men. The Howard J. Crim. Justice, 33: 193-202

Nielsen MM. 2010. Pains and possibilities in prison: on the use of emotions and positioning in ethnographic research. Acta Sociol. 53(4):307-21

Owen B. 1998. In the Mix: Struggle and Survival in a Women's Prison. Albany, NY: State University of New York Press

Palomar Verea C. 2007. Maternidad en Prisión. Guadalajara: Universidade de Guadalajara

Patillo M, Weiman D, Western B. (eds.). 2004. Imprisoning America: The Social Effects of Mass Incarceration. New York: Russel Sage Foundation Press

Phillips C, Earle R. 2010. Reading difference differently? Identity, epistemology and prison ethnography. Br. J. Criminolog. 50(2) pp. 360-78

Piacentini L. 2004. Punishment, Economy and Politics in transition. Cullompton: Willan Publishing

Piacentini L. 2007. Researching Russian prisons: a consideration of new and established methodologies in prison research, in Y. Jewkes (ed.) 2007. Handbook on Prisons. New York: Willan

Pratt J. 2002. Punishment and Civilization. Penal Tolerance and Intolerance in Modern Society. London: Sage

Reed A. 2004. Papua New Guinea's Last Place. Experiences of Constraint in a Postcolonial Prison. Oxford/New York: Berghan Books

Renouard J. 1990. La prison de l'île de Ré: un travail d'équipe. Quest. Pénales, 12 (4): $1-4$

Rhodes L. 2001. Toward an anthropology of prisons. Annu. Rev. Anthropol. 30: 65-87

Rhodes L. 2004. Total Confinement: Madness and Reason in the Maximum Security Prison. Berkeley/Los Angeles/London: University of California Press

Ribeiro GL, Escobar A (eds). 2006. World Anthropologies: Disciplinary Transformations within Systems of Power. Oxford and New York: Berg

Rowe A. 2011. Narratives of self and identity in women's prisons: stigma and the struggle for self-definition in penal regimes, Punishm. \& Soc., 13: 571-91

Ruggiero V, Ryan M, Sim J. (eds) 1996. Western European Penal Systems. A critical anatomy. London: Sage.

Sabaini R. 2011. Uma cidade entre presídios: percepções acerca de um contínuo entre a prisão e o urbano. Soc. \& Territ. Natal, 23 (2): 21-37 
Sabo D, Kupers TA, London W. (eds.) 2001. Prison Masculinities. Philadelphia, PA: Temple University Press

Santoro E. 2005. Modalità punitive e strutture della soggettività. Il carcere democratico: una lettura foucaultiana delle nuove politiche penali, in A. Petrillo (ed), Un lavoro disperso e mutevole: la cartografia sociale di Michel Foucault. Avelino: Sellino Editore

Shearing C. 2001. Punishment and the Changing Face of Governance. Punishm. \& Soc. $3,(2): 203-20$

Sieh EW. 1989. Less eligibility: The upper limits of penal policy. Crim. Justice Policy Rev. 3 (2): 159-83

Simon J. 2007. Governing Through Crime. New York: New York University Press

Sloan J, Drake DH. 2013. Emotional engagements: On sinking and swimming in prison research and ethnography. Crim. Justice Matters. 91 (1): 24-25

Snacken S. 2002. "Normalisation" dans les prisons: concept et défis. L'exemple de l'avant-project de loi pénitentiaire belge, in Schutter, Olivier de et Dan Kaminski (eds) L'institution du droit pénitentiaire - Enjeux de la reconnaissance de droits aux détenus, La pensée juridique, Bruylant L.G.D.J

Snacken S, Van Zyl Smit D. 2009. Principles of European Prison Law and Policy: Penology and Human Rights. Oxford: Oxford University Press.

Sparks R. 2002. Out of the 'Digger': The warrior's honour and the guilty observer. Ethnography. 3: 556-81

Sparks R, Bottoms A, Hay W. 1996. Prisons and the Problem of Order. Oxford: Clarendon Press

Spedding AL. 1999. Dreams of leaving. Life in the feminine penitentiary center, Miraflores, La Paz, Bolivia, Anthropol. Today, 15 (2): 11-17

Sutton JE. 2011. "An Ethnographic Account of Doing Survey Research in Prison: Descriptions, Reflections, and Suggestions from the Field" Qual.

Sociol. Rev. VII (2): 45-63

Sykes G. 1958. The Society of Captives. A Study of a Maximum Security Prison. Princeton: Princeton University Press

Sykes G, Messinger S. 1960. The Inmate Social System, in R. Cloward et al, Theoretical Studies in Social Organization of the Prison. New York: Social Research Council: 5-19

Tonry M. 2004. Thinking about Crime. Sense and Sensibility in American Penal Culture. New York: Oxford University Press 
Tonry M. (ed.). 2007. Crime, punishment and politics in comparative perspective. Chicago, IL: University of Chicago Press

Touraut C .2012. La famille à l'épreuve de la prison. Paris: PUF

Trammell R. 2012. Enforcing the Convict Code: Violence and Prison Culture. Boulder, CO. and London: Lynne Rienner

Travis J, Waul M. (eds.) 2003. Prisoners once removed: The impact of incarceration and reentry on children, families and communities: Washington, DC: Urban Institute Press

Ugger C, Manze J. 2004. "Lost Voices: The Civic and political views of disenfranchised felons" in Patillo, Mary et al. (eds.). Imprisoning America: The Social Effects of Mass Incarceration. Russel Sage Foundation Press: 165-204

Ugelvik T. 2012. Prisoners and their victims: Techniques of neutralization, techniques of the self. Ethnography. 1(13): 259-77

Vakhovine Y. 2004. The (post)-soviet prison subculture faced with the use of selfmanagement doctrines by the corrections administration" Champ Pénal/Penal Field. I. http://champpenal.revues.org/399

Wacquant L. 2002. The curious eclipse of prison ethnography in the age of mass incarceration. Ethnography 3(4): 371-97

Wacquant L. 2008. Urban Outcasts: A Comparative Sociology of Advanced Marginality. Cambridge, UK: Polity Press

Wacquant L. 2009. Punishing the Poor. Duke University Press

Wacquant L. 2013. Deadly Symbiosis: Race and the Rise of the Penal State. Cambridge, UK: Polity Press

Waldram JB. 2009. Challenges of prison ethnography. Anthropol. News 50(1):4-5

Walker S, Worrall A. 2000. Life as a woman. The gendered pains of indeterminate imprisonment. Prison Serv. J. 132: 27-37

Walmsley R. 2011. World Prison Population List. Essex: International Center for Prison Studies. $9^{\text {th }}$ ed.

Ward D, Kassebaum G. 1965. Women's Prison: Sex and Social Structure. Chicago: Aldine

Western B. 2006. Punishment and Inequality in America. New York: Russell Sage

Whitman JQ. 2003. Harsh justice: criminal punishment and the widening divide between America and Europe. New York: Oxford University Press 
Zaitzow B, Thomas T. (eds.) 2003. Women in Prison: Gender and Social Control. Boulder CO: Lynn Rienner Publishers 


\title{
Table of contents:
}

The workings of the institution

The prison outside walls

The prisoners' social and subjective world

Reflexivity in prison field research

\section{Keywords}

prison ethnography, prison-society relations, prison boundaries, prison culture, prison experiences.

\begin{abstract}
Centered on the ethnography of prisons and field research on penal confinement, this review maps out the main current developments and characterizes them in relation to key themes that shaped earlier approaches. Further internationalizing the ethnographic discussion on prisons by broadening the predominant focus on the US and the Englishspeaking world, the review is organized around a main line of discussion: the "prisonsociety" relation and the articulation between intramural and extramural worlds. More or less apparent in field research, this articulation is addressed from different perspectives within and across different scales and analytic frames -, whether more centered on the workings of the institution, or on prisoners and their social world, both within and outside walls. The porosity of prison boundaries, increasingly acknowledged, has also been problematized and ethnographically documented in different ways: from "prison-incontext" to "interface" approaches, both more reflexive and attuned to broader theoretical debates.
\end{abstract}


${ }^{1}$ A similar purpose was pursued in the recent symposium Resisting the Eclipse: An International Symposium on Prison Ethnography, and the resulting special issue in the journal Criminal Justice Matters (2013).

2 See Walmsley (2011) for an overview. Behind this general trend in prison demography, there are nevertheless differences in penal cultures and in the use of custodial confinement between the US and Europe (Pratt 2002, Tonry 2004, 2007).

3 At a broader level, but running parallel to these intra-institutional coexistences between apparently opposite tendencies, M. Gottschalk (2006) showed how the severity of punishment and the punitive turn that resulted in the hyperincarceration in the US occurred in the aftermath of prison reforms intended to improve prisoners' rights.

${ }^{4}$ Unlike the US (Mele and Miller 2005), most European countries and other democracies do not disenfranchise felons, and prisoners continue to participate in the political system by exercising voting rights.

${ }^{5}$ See for example the normalization processes in French penal institutions under the lexicon of "entering common rights" (faire rentrer dans le droit commun), Bouagga (2012).

${ }^{6}$ See the European Prison Rules that since 1987 detail formal guidelines for the prison administrations of the European Council member states, and the action of the European Court of Human Rights (Snacken and Van Zyl Smit 2009).

${ }^{7}$ This type of interaction between formal and informal structures of authority tends rather to occur within an authoritarian discretionary model of management. Two of the models of correctional management identified by I. Barak-Glanz (1981) in the US are also relevant in the history of European penal institutions: the "authoritarian model" and the "bureaucratic-lawful model" (see also Vakhovine 2004 for the former Soviet republics). The latter has gradually prevailed on both sides of the Atlantic. Prison ethnographies have shown how these shifts have deeply shaped contemporary prison life on different interrelated levels (e.g. Crewe 2009, Cunha 2002).

${ }^{8}$ For an overview, see Mills and Codd (2007), Patillo et al (2004), Travis and Waul (2003).

${ }^{9}$ Despite this recurrence, ethnographic accounts around the same period showed a less uniform in-prison cultural landscape (see below studies on women's prisons and Mathiesen's account on a Norwegian prison (1965).

${ }^{10}$ For prisoner's participatory experiences in research processes see Bosworth et al (2005).

${ }^{11}$ This caution is all the more necessary as the increased penalisation of perceived others is affecting the prison landscape in different continents (Wacquant 2013.) 